\title{
Todd J. Albert and Alexander R. Vaccaro: Physical examination of the spine
}

\section{2nd Edition, Thieme Verlag, New York, Stuttgart, Delhi, Rio de Janeiro, 2017, 164 pp.; num III. Hardcover, 54.49€, ISBN: 978-1-62,623-320-1}

\author{
Pierre Kehr ${ }^{1}$. Alain G. Graftiaux ${ }^{1}$
}

Received: 31 October 2017 / Accepted: 17 November 2017 / Published online: 28 November 2017

๑) Springer-Verlag France SAS, part of Springer Nature 2017

This little book is interested in the first intake in charge of a patient who complains about the spinal column.

This book is divided into four great chapters dealing with fundamental (anatomy and classifications) then of the three various parts of the column: cervical, thoracic and lumbar. Inspection, palpation, movements, of the various tests, and finally the neurological evaluation are detailed.
It will allow the surgeon beginning as with more experienced importance of the clinical examination before going further in the complementary examinations.

\section{Compliance with ethical standards}

Conflict of interest The authors declare that they have no competing interests.

Pierre Kehr

pierre.kehr@gmail.com

1 Strasbourg, France 